\title{
PUBLIC PRIVATE PARTNERSHIPS IN URBAN WASTEWATER MANAGEMENT: THE ADELAIDE EXPERIENCE AND LESSONS FOR DEVELOPING COUNTRIES
}

\author{
Ganesh Keremane*
}

\begin{abstract}
The concerns about the availability of freshwater to meet the demands of a growing population while sustaining a healthy natural environment are based on several factors: uncertainties as to the availability of supplies; the high costs of developing additional water supplies; the vulnerability of the resource and the problems of restoring and protecting valued surface and groundwater resources; the importance of reliable supplies of high-quality water for human and environmental health and economic development; and the shortcomings of our institutions for allocating scarce supplies in response to changing supply and demand conditions. Therefore water management authorities around the world are challenged with ensuring the quantity, quality, and allocation among the various uses of water are sustainable.
\end{abstract}

This paper is based on the household survey of the irrigators using recycled water from the scheme to irrigate their crops in Virginia. The paper elicits their point of view on various issues related to wastewater usage and the rules-in-use governing wastewater management related to the scheme.

Keywords: humankind, freshwater, public private partnership, recycled water, Adelaide, Australia.

\section{INTRODUCTION}

Freshwater availability to meet the growing needs of humankind has raised serious concerns in the recent past. Providing the water needed to feed a growing population and balancing this with all the other demands on water, is one of the great challenges of this century (UNESCO, 2006). The concerns about the availability of freshwater to meet the demands of a growing population while sustaining a healthy natural environment are based on several factors: uncertainties as to the availability of supplies; the high costs of developing additional water supplies; the vulnerability of the resource and the problems of restoring and protecting valued surface and groundwater resources; the importance of reliable supplies of high-quality water for human and environmental

\footnotetext{
${ }^{*}$ Mr. Keremane is associated to School of Commerce, Centre for Comparative Water Policies and Laws and National Centre for Groundwater Research and Training, University of South Australia, Adelaide - 5001, Australia.
} 
health and economic development; and the shortcomings of our institutions for allocating scarce supplies in response to changing supply and demand conditions (Keremane \& McKay, 2009). Therefore water management authorities around the world are challenged with ensuring the quantity, quality, and allocation among the various uses of water are sustainable (UNESCO, 2003). But developing additional surface water supplies is expensive, and water planners and policy makers need to think of development and use of new/alternative sources of supply to address perceived new demands (Gleick, 2000). Accordingly concepts such as water reclamation, recycling and reuse are now key components of water and wastewater management policies around the world.

But successful integration of water recycling into future sustainable water management policy encounter various impediments such as costs compared to other water sources, acceptance by the public, minimization of environmental and health impacts, and technology to treat water to an appropriate standard. Furthermore, the ability of the government(s) which traditionally provided public services and infrastructure has been severely stretched due to increasing population pressure, urbanisation, and other developmental trends. So in recent years public-private partnerships have been advocated for providing public services and infrastructure. The question now is 'Does private sector participation simplifies the process of integrating water recycling into future sustainable water management policy?' Accordingly this paper focuses on a single case study project in Adelaide, South Australia and seeks to assess the current management practices and related policies, institutions, organisations and actors in wastewater management.

\section{PUBLIC SECTOR PARTICIPATION IN THE WATER SECTOR}

As mentioned earlier reasons such as inefficiency, corruption and lack of funds with the public utilities to extend the access to services within the water and sanitation sector have prompted increased community and private sector involvement to address these problems. In other words, there has been growing use of "project alliances" on the water and sanitation sector worldwide mainly to establish and manage the relationships between all stakeholders, remove barriers, encourage maximum contribution, and ultimately achieve win-win outcomes (Budds \& McGranahan). There are varying opinions about PSP in water sector; but in general it refers to a contractual agreement involving a public agency and a private company and the private agencies can be large water companies (usually multi-national) to small-scale informal operators or civil societies. Similarly, the forms or models of private sector involvement also vary based on the allocation of responsibilities.

According to Grimsey and Lewis (2004, p. 2), "any relationship involving some combination of the private, and public sectors is prone to be labelled a partnership". Sharing of responsibility and/or authority between the parties involved is an essential ingredient of partnership (Townsend \& Mooley, 1995). According to Caplan et al. (2001), 
a partnership is just a means for delivering the project objectives; therefore, the need today is to implement and enforce the rules under which private or public agencies are made efficient and responsive to social needs and desires (Wolff \& Palaniappan, 2004). Worldwide, numbers of examples of this cooperation or collaboration in various forms exist (see Grimsey \& Lewis, 2004); one of the most promising forms of partnership is the Public-Private Partnership (UNDP, 1999). It is also the model on which the reuse scheme under study is developed and implemented.

Public-Private Partnerships, popularly known as PPPs, describe a spectrum of possible relationships between public and private actors for the cooperative provision of infrastructure services (UNDP, 1999). Grimsey and Lewis (2004, p. 2) see PPPs as a "contract for a private entity to deliver public infrastructure-based service". In line with this definition, in the context of the water sector, PPPs refer to "public entity entering into a contractual agreement with private sector to take over some or all of its activities related to water management" (UNDP, 1999; OECD, 2003; ADB, 2000). Thus, through PPPs, the social responsibility, environmental awareness, and local knowledge of the public sector can be combined with the innovation, access to finance, technology, managerial efficiency, and entrepreneurial spirit of the private sector in order to solve urban problems (UNDP, 1999).

Generally, PPPs are misunderstood as 'privatisation', but they differ from privatisation. Grimsey and Lewis (2004) state that two major differences - regulation through contract and the lack of government disengagement in case of the PPPs - differentiate them from privatisation. In privatisation, the management and ownership of the water infrastructure are completely transferred to the private sector, while, in the case of a PPP, the ownership of the assets of the water utility remains with the government, and only the management is contracted out to professional management, which is held accountable and has appropriate incentives to ensure effective delivery and reduce waste (OECD, 2003; ADB, 2000). The only essential criterion with respect to PPP is some degree of private participation in the delivery of traditionally public-domain services. However, as stated by Grimsey and Lewis (2004, p. 55), "PPPs might still be seen as privatisation in all but name, as they are by many public sector unions."

\section{OPTIONS FOR PUBLIC-PRIVATE PARTNERSHIPS}

Options for PPPs can be tailored to satisfy very specific needs; however, for PPP to work to the advantage of the concerned country, it is always important to ensure that social and environmental issues are taken into account (Requena \& Lamrani, 2002). The literature provides us with a wide range of options for involving the private sector that might be applicable to the water (irrigation) sector (OECD, 2003, UNDP, 1999; Finlayson, 2002; Requena \& Lamrani, 2002). According to Pierson and McBride (1996), cited in Grimsey and Lewis (2004, p. 2), the mechanics of the arrangements can take many forms and may incorporate some or all of the following features: 
- the public sector entity transfers land, property or facilities controlled by it to the private sector entity (with or without payment in return) for the term of the arrangement;

- the private sector entity builds, extends or renovates a facility;

- the public sector entity specifies the operating services of the facility;

- services are provided by the private sector entity using the facility for a defined period of time (usually with restrictions on operations standards and pricing); and

- the private sector entity agrees to transfer the facility to the public sector (with or without payment) at the end of the arrangement.

Table 1 provided in the appendix illustrates the different forms of PPP and the allocation of public/private responsibilities across these forms.

\section{BACKGROUND OF THE VIRGINIA PIPELINE SCHEME}

The case studied is the Virginia Pipeline Scheme (VPS) operating in the Northern Adelaide plains of South Australia. The scheme is named after the township of Virginia near Adelaide and is South Australia's 'Vegie Bowl' because of its reputation for delivering high quality horticultural produce to local, interstate and overseas markets.

The horticulture industry in this region has historically relied on ground water resources for its irrigation water supply. However, as a result of over-use of these resources for irrigating horticultural crops, the water levels in the aquifers have declined and groundwater has become a really scarce resource. The groundwater resource has provided about 18,000 megalitres per year, which is beyond sustainable limits (Kracman, Martin \& Sztajnbok, 2001). Because of the depletion of ground water resources in the region, several growers have been using Class ' $C$ ' reclaimed water to irrigate their market gardens, by pumping reclaimed water from the Bolivar wastewater treatment plant out-fall channel through reticulation pipelines they installed themselves. Thus, these growers had already realised the potential of this new source of water in providing a secure supply for irrigating their croplands. This realization and environmental, economic and social pressures led to the development of the Virginia Pipeline Scheme (Thomas, 2006).

The scheme is built on the build-own-operate-transfer (BOOT) model, and is the largest of its type in the whole of Australia. The main elements of the scheme consist of a treatment plant at Bolivar, a storage reservoir, and 150 kilometres of distribution pipe work (Collins, 2005). 
The scheme is a co-operative undertaking of the VIA, representing market gardeners and other irrigators; SA Water and WRSV (Water Reticulation Services Virginia), a private company. The proposal for developing the VPS was envisioned when the SA Water Corporation, as part of its Environment Improvement Program (EIP), constructed a filtration/disinfection plant (DAFF) costing AUD 30 million to treat lagoon effluent from the Bolivar wastewater treatment plant. This resulted in the production of Class A reclaimed water, which instead of being disposed of to the receiving waters, could be used for irrigation of the market gardens in the region, whose groundwater resources were already over-used. A private water company, WRSV, won a contract from the SA Water Corporation to access the output from the treatment plant, and also signed up clients for the reclaimed water and built the water distribution system. Since the project is built on the BOOT model, the project will be returned to the ownership of SA water by WRSV in 2019, at the end of the contract term. The total cost of the project (AUD 55million), including the DAFF plant and the reticulation system, was shared between a Commonwealth Government contribution from the Building Better Cities funds (AUD 10.8 million); a Landcare contribution (AUD 574,000); private investors' contributions (AUD 7 million); SA government funds (AUD 7 million); the remainder was contributed by SA Water. As a result of the effective partnerships between the public and private entities, along with the collective efforts of the community, the scheme was finally commissioned in 1999, and since then has been operating successfully. As of 2005, the scheme supplies Class-A treated water to around 252 growers in the township of Virginia. See Table 2 for the classifications of reclaimed water for various uses in South Australia.

\section{RESULTS AND DISCUSSION}

This paper is based on the household survey of the irrigators using recycled water from the scheme to irrigate their crops in Virginia. The paper elicits their point of view on various issues related to wastewater usage and the rules-in-use governing wastewater management related to the scheme.

\section{Factors Prompting Implementation of the Scheme}

Generally, whenever individuals face problems unsolvable on their own they tend to come together to find solutions, so that when there is a crisis that several groups acknowledge is affecting their core interests, collective action is possible (OECD, 2003). Collective action then becomes an immediate necessity rather than a choice. According to Wade (1979), when water is problematic for almost all of a group of irrigators, they tend to co-operate to deal with irrigation and cultivation problems. An initial exploration study and discussions with key stakeholders had revealed that the region faced serious groundwater shortages and that reclaimed water was the only alternative available to meet the water demands. The setting up of VPS was seen as a way to attain the desired environmental outcomes and meet the challenge caused by these shortages (Kracman, Martin and Sztajnbok, 2001; Thomas, 2006). So what 
was the most important reason that prompted development of the Virginia pipeline (Figure 1).

Around $53 \%$ of the respondents nominated groundwater depletion as the most important reason; $32 \%$ cited the price of mains water, while $7 \%$ said community interest in the use of reclaimed water was the important reason. About $6 \%$ mentioned encouragement by water authorities as the important reason, while only $2 \%$ said that previous experience of using the reclaimed water was instrumental in implementing the scheme. However, these are only the perceptions of the irrigators. In field settings, the scheme is the result of a combination of all these factors; as well as the factors perceived by the respondents, there were others, such as increasing public concern about the environmental damages caused by discharge of nutrient-rich effluents into the ocean; government initiatives such as the Building Better Cities Environment Improvement Program, were also instrumental in initiating this scheme.

The other important aspect of the VPS is the innovation with respect to the partnerships developed for achieving a common goal. It represents a case of well-designed 'publicprivate partnership' that has led to the success and sustainability of VPS.

\section{Framework of Partnerships in the VPS}

Within the water sector, a public-private partnership amounts to 'a public entity entering into a contractual agreement with the private sector to take over some or all of its activities related to water management' (OECD, 2003). In general, publicprivate partnerships (PPPs) promoted within the water sector are concession-based contracts in which a private firm obtains from the government the right to provide a particular service under conditions of significant market power (Kerf et al., 1995, cited in Braadbaart, 2005). Such contracts come in three flavours: franchise contracts, concession contracts and build-own-operate-transfer (BOOT) contracts (Braadbaart, 2005).

Implementation of the VPS was largely possible because of the enhanced participation of the stakeholders in effectively designed partnerships through contractual agreements between the stakeholders. As a part of the contractual agreement this scheme follows the Build Own Operate Transfer (BOOT) model.

In a BOOT project, a private company is given a concession to build and operate a facility, that would normally be built and operated by the government, and at the end of the contract period it is transferred back to the government (UNIDO, 1996, cited in Braadbaart, 2005). So in this case a private consortium (WRSV) is responsible for building and operating the Virginia pipeline scheme, until the whole scheme is returned to the ownership of SA water at the end of the BOOT period (Keremane \& McKay, 2007). Under this form of partnership, capital investment, designing and 
building, and operation of the scheme is the responsibility of the private sector, while the responsibility for setting performance standards, asset ownership, user fee collection, and oversight of performance and fees rests with the public agency; in the present case, SA water. The private company (WRSV) is responsible for designing, building and operating the scheme, as well as capital investment with contributions from SA water, State and the Federal governments in the proportions described at the beginning of this chapter.

To ensure that the irrigation of the agricultural land is sustainable, an Irrigation Management Plan (IMP) is developed. The responsibility for reporting deviations, if any, from the plan is assigned to WRSV. Ensuring that all environmental legislation is complied with is the responsibility of the Environment Protection Agency (EPA), which is also responsible for approving and reviewing the irrigation management plans on an annual basis. The irrigation association (VIA), representing the community/irrigators, is assigned the responsibility for managing an education programme for growers in relation to water reuse. Through this programme the VIA educates the irrigators about the impact of the enhanced nutrient levels on soils and natural groundwater due to the use of reclaimed water. It also closely monitors the effects of the reclaimed water on the soils. In addition, these arrangements also helped tackle the impediments - legal, policy, institutional, financial and social - that usually face the implementation of any reuse scheme.

As already mentioned, commencement of VPS can be seen as the outcome of an organised collective effort of the irrigators who wanted to find solutions to the water scarcity crisis caused by depleting groundwater resources. So, how did the irrigators' perceive collective action and participation? The results are presented in Tables 3. More than $75 \%$ of the respondents agreed that 'most people in the community are willing to help when in need'. When asked about their perception of community prosperity over the last five years, around $76 \%$ believed that the community had prospered because of cooperation among its members. Keeping in mind their variations in cultural background and ethnicity, the respondents were asked if they felt accepted as a member of a community. More than $70 \%$ agreed that they felt accepted. When specifically asked about cooperating during a water crisis, about $59 \%$ agreed that people cooperate in such situations.

Generally, reuse schemes span different agencies. In this case, the VPS is a co-operative undertaking and involves different agencies and trust in these agencies plays an important role in decisions about participation in the scheme. Respondents were asked about their level of trust in the agencies: government, EPA, health department and the water company (see Figure 2).

The irrigators had either complete trust or some level of trust in these agencies to perform their duties effectively. Around $58 \%$ of the respondents had complete trust in 
the government agencies, while another $16 \%$ had some level of trust. As for the water company, more than $55 \%$ had complete trust while around $26 \%$ more had some level of trust. About other associated agencies, like the EPA and the Health Department, more than $40 \%$ had complete trust in them. However, the percentage of respondents who were indifferent is considerable, particularly with respect to EPA and Department of Health. This may be due the lack of awareness among the irrigators of the roles of these agencies in relation to the scheme.

It is evident from the success of the scheme that, despite different ethnicities and cultural backgrounds, the irrigators have demonstrated a high degree of networking; without this there might have been problems. This contradicts the argument on collective action that divisions between irrigators due to cultural and/or other social differences affect their capacity to communicate with one another (Tang, 1992). Thus the findings of this study suggest that relatively heterogeneous community groups can be effective at provision of irrigation services (Kurian \& Dietz, 2005). It also demonstrates a high level of trust among the members of the community.

\section{Irrigators' Perception of the 'Rules-In-Use'}

Institutional arrangements are described using different terminologies by researchers studying common pool resources management and collective action (Tang, 1992). However, in this case, we consider it to be the rules-in-use that stipulate who can participate in the scheme as appropriators and providers; what participants may, must or must not do; and how they will be rewarded or punished. These rules are conceptualised in the commons literature as "operational rules" (Tang, 1992, p. 81).

In order to elicit the perceptions of the irrigators about these rules-in-use they were presented with propositions and asked to indicate their degree of agreement with each of them (see Figure 3).

When asked whether the rules governing water distribution were clear, around $60 \%$ of the irrigators agreed that the rules were clearly defined, with $34 \%$ strongly agreeing with this. About the process of water sharing or distribution within the scheme, more than $65 \%$ agreed that the process was appropriate and the results were similar when asked about the basis for allocating the water from the scheme, when more than $65 \%$ agreed that the allocation was fair. However, a significant number $(31 \%)$ of the irrigators were neutral on this proposition. When they were asked about the water use charges and the basis of fixing them, most growers (50\%) generally understood the price structure and were happy with the current price of the water (Marks \& Boon, 2005). Nevertheless, a significant percentage of the irrigators remained neutral. Perhaps this reflected their dissatisfaction with the 'take or pay' policy, as they were concerned about paying for an allocation whether or not they used the water. 
The survey went on to ask further whether all the irrigators were involved in decision making processes, particularly in modifying the rules governing the use of wastewater from the scheme. Around 34\% disagreed with this proposition, stating that not all the irrigators were involved. It was observed that unlike some other self-governed institutions managing common pool resources, where the users create and modify the rules (Keremane \& McKay, 2006; McKay \& Keremane, 2006a; Keremane, McKay \& Narayanamoorthy, 2006), in this case the contractual agreement between the irrigators and the water company took care of these issues. This might have been the reason for the irrigators being neutral about water allocation and fees.

Generally, in natural resource management, conflicts arise due to disagreement over access, control and use of natural resources (Matiru, 2000). It is more so with water because it has become a scarce resource in limited supply. So in this study the irrigators were presented with some propositions related to conflict and its management (see Figure 3).

When asked if conflicts between the water company and the irrigators was common (common implying frequently occurring), around $41 \%$ of the irrigators remained neutral, around $35 \%$ disagreed, while about $22 \%$ agreed with the statement. This indicated some conflict; when the water company was asked about this, they said otherwise and also claimed there was no chance for conflict, as "everything is clearly mentioned in the contractual agreement and they adhere to it". Earlier results had shown that there was a strong sense of cooperation within the community; however the irrigators were asked if there were any conflicts with neighbours on water use; the results supported the previous observations, as $70 \%$ of the irrigators disagreed that there were conflicts between the water users. Although the water company had insisted there was no scope for conflict, the survey went on to ask the irrigators whether there were any conflict resolution measures mentioned in the agreement in case they should occur. More than $50 \%$ of them were neutral, indicating that they were not aware of any such measures. There was a similar response when they were asked about sanctions on offenders.

On a more general note, when the irrigators were asked if they believed that the rules were enforced as formulated, around $70 \%$ agreed that they were. Furthermore, over $40 \%$ felt that there was no influence from large farmers, which could be true, given that most of the farmers associated with the scheme were market gardeners.

\section{Impediments Encountering Implementation of Reuse Schemes}

In a situation where competition for high quality freshwater is manifold, reclaimed water is increasingly being recognized as a new and reliable water source that does not compromise public health. All the same, developing successful and sustainable wastewater irrigation schemes faces various difficulties, among which legal, policy, institutional, financial and social impediments occupy a prominent place. 
These problems arise due to coordination complexity resulting from the varying roles and responsibilities and overlapping concerns of the public agencies managing the resources (MacDonald \& Dyack, 2004). As well, wastewater collection, treatment, and usage span a wide range of interests at different levels of administration, so the success and long-term sustainability of any reuse scheme depends largely on institutional organization. My field observations and discussions with the key stakeholders associated with the VPS revealed that these issues can be effectively addressed through community participation and partnerships between the public and private entities.

Legal and policy issues were addressed effectively, because South Australia has a favourable regulatory and policy regime for wastewater reuse. The government policy "to phase out all sewerage discharges to the marine environment where it is economically and environmentally sustainable" has significantly influenced the development of water reuse programs in South Australia (Thiyagarajah, 2005). The inclusion of reclaimed water in the South Australian Government's State Water Plan 2000 demonstrates the State's commitment to wastewater reuse projects. Above all, the state has several regulatory controls that need to be complied with before implementation of any scheme, including comprehensive guidelines on reclaimed water; the Water Resources Act; approval by the Public and Environmental Health Service, and approval by the Environment Protection Authority (EPA).

The financial, institutional and social issues were addressed through contractual agreements between the stakeholders - SA Water, VIA, and the WRSV. As a part of the agreement, SA water constructed the DAFF water treatment plant. The WRSV built the distribution system and delivers water to dams on individual growers' properties, from which they pump the water into their own irrigation systems. All properties using recycled water need to have signs on fencing reading 'Reclaimed water - do not drink'. The supply contracts with the irrigators are with the water company, who owns the scheme at present and will transfer it to SA Water in 2019, by the terms of agreement.

As for financial aspects, the total cost of the project, including the DAFF Plant and the reticulation system, was shared between the Commonwealth Government, Landcare, private investors, the SA government, and the SA Water Corporation.

\section{CONCLUSIONS}

Development of successful and sustainable water reuse projects will definitely provide solutions to water scarcity problems. However, we cannot overlook the impediments facing implementation of any reuse scheme. Conflicting agendas among water agencies; addressing water rights issues; dealing with opponents to recycling/reuse; modifying existing regulations and acquiring funding are some of the challenges to successful development encountered by reuse schemes. 
Experience from the VPS suggests that, through collective action, enhanced community participation and well-designed partnerships, it is possible to coordinate individuals' activities; develop rules for resource use; impose sanctions on violators and mobilize the necessary financial, labour and material resources (Agarwal \& Ostrom, 1999). By providing knowledge and information on current best practice and communicating this information in a form that is understandable to the different stakeholder groups, it is possible to implement sustainable reuse schemes. This also influences the user's willingness to pay; the study found that willingness to pay for reclaimed water is influenced by various factors, such as the perceived benefits of the new facility, trust in the regulatory authorities, and perception of ownership and understanding about the use and management of reclaimed water.

Fresh water scarcity and its associated problems are acknowledged world-wide. On the other hand, use of reclaimed or low quality water for potable and non-potable use has emerged as an innovative alternative option to augment continuously depleting freshwater supplies. However, for the latter option, use of this valuable resource imposes concerns about its suitability to sustain development, because of various issues related to wastewater usage and application. But as evidenced in the case of the Virginia Pipeline scheme, it can be said that by providing knowledge and information on current best practice, and communicating this information in a form that is understandable to the key stakeholder groups, any form of reuse can achieve sustainability, with its economic, social and environmental dimensions. Therefore, with sound policies, proper planning and management, sufficient financial commitments, and public awareness, support and participation it is possible to attain sustainability. Here are few suggestions from the VPS experience for the development of reclaimed water irrigation schemes in the future:

- Specific guidelines for wastewater use and management should be located and prepared.

- Awareness programmes regarding the legal, social, economic, environmental, and health issues related to waste water should target all key stakeholders.

- The private sector should play a key role in wastewater treatment and management.

- Enhanced community participation is crucial to achieving sustainability.

\section{References}

Agarwal, A. \& Ostrom, E. (1999). Collective action, property rights, and devolution of forest and protected area management. Paper presented at Workshop on collective action, property rights and devolution of natural resources management, Puerto Azul, the Philippines, 21-25 June 1999.

Asian Development Bank (2000). Public-Private Partnerships in the Social Sector: Issues and Country Experiences in Asia and the Pacific, (ADBI Policy Paper No. 1). Tokyo, Japan: Author. 
Braadbaart, O. (2005). Privatizing water and wastewater in developing countries: assessing the 1990s experiments. Water Policy, 7, 329-344.

Budds, J. \& McGranahan, G. (2003). Are the debates on water privatization missing the point? Experiences from Africa, Asia and Latin America. Environment and Urbanization, 15 (2), 87-113.

Caplan, K., Heap, S., Nicol, A., Plummer, J., Simpson, S. \& Weiser, J. (2001). Flexibility by design: lessons from multi-sector partnerships in water and sanitation projects, London. Business Partners for Development, Water and Sanitation Cluster. Retrieved January 12, 2012, from http://www.bpdws.org/english/docs/flexibility.pdf

Collins, J. (2005). Personal communication. Water reticulation services Virginia, Northern Adelaide Plains, Adelaide.May, 2005.

Finlayson, J. (2002). The what and why of public-private partnerships. Policy Perspective, 9(1), $1-6$.

Gleick, P.H. (2000). The changing water paradigm: A look at twenty-first century water resources development, Water International, 25 (1), 127-138.

Grimsey, D. \& Lewis, M. K. (2004). Public Private Partnerships: The worldwide revolution in Infrastructure provision and project finance. UK and USA: Edward Elgar Publishing Limited.

Keremane, G. B., \& McKay, J. M. (2006). The role of community participation and partnerships: The Virginia pipeline scheme. Water, 29 (34), 29-33.

Keremane, G. B., \& McKay, J. (2007). Successful wastewater reuse scheme and sustainable development: A case study in Adelaide. Water and Environmental Journal, 21(2), 83-91.

Keremane, G. B., McKay, J. M., \& Narayanamoorthy, A. (2006). The decline of innovative local self-governance institutions for water management: The case of Pani Panchayats. International Journal of Rural Management, 2(1), 107-122.

Keremane, G. B., \& McKay, J. (2009). Critical success factors (CSFs) for private sector involvement in wastewater management: the Willunga pipeline case study. Desalination, 244(1-3), 248-260.

Kracman, B., Martin, R., \& Sztajnbok, P. (2001). The Virginia pipeline: Australia's largest water recycling project. Water Science and Technology, 43(1), 35-42.

Kurian, M., \& Dietz, T. (2005). How pro-poor are participatory watershed management projects?An Indian case study. (Research Report 92). Colombo, Sri Lanka: International Water Management Institute.

MacDonald, D. H., \& Dyack, B. (2004). Exploring the institutional impediments to conservation and water reuse -National issues. CSIRO Land and Water Client Report.

Marks, J. S., \& Boon, K. F. (2005). A Social Appraisal of the South Australian Virginia Pipeline Scheme: Five year's experience. Report to Land \& Water and Horticulture Australia Ltd, $20^{\text {th }}$ May, Flinders University, Adelaide.

Matriu, V. (2000). Conflict and natural Resource Management. Rome: FAO 
McKay, J. M. \& Keremane, G. B. (2006). Farmers' perception on self-created water management rules in a pioneer scheme: The Mula irrigation scheme, India. Irrigation and Drainage Systems, 20, 205-223.

Organization for Economic Co-operation and Development (2003). Public-private partnerships in the urban water sector. OECD Policy Brief, April.

Requena, S., \& Lamrani, H. (2002). Options and challenges for PPP in irrigation. Paper presented at the Middle East and North Africa Regional Consultation for the 3rd World Water Forum, Spain, 10-12 June.

Tang, S. Y. (1992). Institutions and collective action: self-governance in irrigation. ICS press, San Francisco, CA.

Thiyagarajah, A. R. (2005). Sustainable wastewater reuse through private sector participation - the Adelaide experience. Retrieved September 2, 2005, from http:// www.adb.org/

Thomas, R. (2006). Reuse in South Australia. In D. Steven (Ed.). Growing crops with reclaimed wastewater (pp. 6-14). Victoria, Australia: CSIRO Publishing.

Townsend, R.E., \& Pooley, S. G. (1995). Distributed governance in fisheries. In S.Hanna, \& M.Munasinghe (Eds.). Property rights and the environment-social and ecological issues. Washington, D.C.: The Beijer International Institute of Ecological Economics and the World Bank.

United Nations Educational, Scientific and Cultural Organization (2003).Water for people, water for Life. The United Nations World Water Development Report 1. Paris, France: UNESCO/Berghahn Books.

United Nations Educational, Scientific and Cultural Organization (2006).Water a shared responsibility. The United Nations World Water Development Report 2. Paris, France: UNESCO/Berghahn Books.

United Nations Development Programme (1999). Public-private partnerships for the urban environment. UNDP/PPPUE Conference Paper Series, Volume III: UNDP, New York and Carl Duisberg Gesellschaft e.V. (CDG), Germany.

Wade, H. R. (1979). The social response to irrigation: an Indian case study. Journal of Development Studies, 16(1), 3-26.

Wolff, P. E., \& Palaniappan, M (2004). Public or private water management? Cutting the Gordian knot. Journal of Water Resource Planning and Management, 130(1), 1-3. 
Table 1: Options for Private sector Involvement in Water Sector and Allocation of Responsibilities

\begin{tabular}{|l|c|c|c|c|c|}
\hline \multicolumn{1}{|c|}{ Model $\rightarrow$} & $\begin{array}{c}\text { Service } \\
\text { Responsibilities } \downarrow\end{array}$ & $\begin{array}{c}\text { Management } \\
\text { contract }\end{array}$ & Lease/affermage & Concession & Divestiture \\
\hline Asset ownership & Public & Public & Public & Public & Private \\
\hline Capital investment & Public & Public & Public & Private & Private \\
\hline Commercial risk & Public & Public & Shared & Private & Private \\
\hline $\begin{array}{l}\text { Operations/ } \\
\text { maintenance }\end{array}$ & $\begin{array}{c}\text { Private/ } \\
\text { Public }\end{array}$ & Private & Private & Private \\
\hline Contract duration & $1-2$ years & 3-5 years & $8-15$ years & 20-30 years & Indefinite \\
\hline Description ${ }^{\text {a }}$ & $\begin{array}{l}\text { Short-term } \\
\text { agreements } \\
\text { for a specific } \\
\text { task }\end{array}$ & $\begin{array}{l}\text { Government } \\
\text { transfers } \\
\text { certain O\&M } \\
\text { responsibilities } \\
\text { but retains } \\
\text { other }\end{array}$ & $\begin{array}{l}\text { Government } \\
\text { transfers } \\
\text { all O\&M } \\
\text { responsibilities } \\
\text { manages the } \\
\text { entire utility } \\
\text { and government } \\
\text { retains the } \\
\text { ownership of } \\
\text { assets }\end{array}$ & $\begin{array}{l}\text { Government } \\
\text { transfer the water } \\
\text { business to private } \\
\text { infrastructure on a } \\
\text { permanent basis }\end{array}$ \\
\hline
\end{tabular}

Source: Modified from Budds and McGranahan, 2003

Note: ${ }^{a}$ See Budds, J. and McGranahan, G. (2003) for further description of the models

Table 2: Classification of Reclaimed Water for use in South Australia

\begin{tabular}{|c|c|c|c|}
\hline Class & Typical treatment process & $\begin{array}{c}\text { Microbiological, chemical \& } \\
\text { physical criteria }\end{array}$ & Uses \\
\hline Class A & $\begin{array}{l}\text { Full secondary plus } \\
\text { tertiary filtration plus } \\
\text { disinfection. Coagulation } \\
\text { may be required to meet } \\
\text { water quality requirements }\end{array}$ & $\begin{array}{l}<10(\text { E. coli/100ml); } \\
\leq 2 \mathrm{NTU} \text { (Turbidity); }<20 \mathrm{mg} / \mathrm{L}(\mathrm{BOD}) \\
\text { Chemical content to match the use }\end{array}$ & $\begin{array}{l}\text { Residential non-potable; } \\
\text { Municipal use with public } \\
\text { access; Unrestricted crop } \\
\text { irrigation }\end{array}$ \\
\hline Class B & $\begin{array}{l}\text { Full secondary plus } \\
\text { disinfection }\end{array}$ & $\begin{array}{l}<100(\text { E. coli/100ml); } \\
<20 \mathrm{mg} / \mathrm{L}(\mathrm{BOD}) \\
<30 \mathrm{mg} / \mathrm{L}(\mathrm{SS}) \\
\text { Chemical content to match the use }\end{array}$ & $\begin{array}{l}\text { Municipal use with } \\
\text { restricted access; Restricted } \\
\text { crop irrigation; Irrigation } \\
\text { of pasture and fodder for } \\
\text { fodder animals. }\end{array}$ \\
\hline Class C & $\begin{array}{l}\text { Primary sedimentation } \\
\text { plus lagooning OR Full } \\
\text { secondary (disinfection if } \\
\text { required to meet microbial } \\
\text { criteria only) }\end{array}$ & $\begin{array}{l}<1000(\text { E. coli/100ml); }<20 \mathrm{mg} / \\
\mathrm{L}(\mathrm{BOD}) ; \quad<30 \mathrm{mg} / \mathrm{L}(\mathrm{SS}) ; \\
\text { Chemical content to match the use }\end{array}$ & $\begin{array}{l}\text { Municipal use with } \\
\text { restricted access; Restricted } \\
\text { crop irrigation; Irrigation } \\
\text { of pasture and fodder for } \\
\text { fodder animals. }\end{array}$ \\
\hline Class D & $\begin{array}{l}\text { Primary sedimentation } \\
\text { plus lagooning OR Full } \\
\text { secondary }\end{array}$ & $\begin{array}{l}<10000(\text { E. coli } / 100 \mathrm{ml}) ; \text { Chemical } \\
\text { content to match the use }\end{array}$ & $\begin{array}{l}\text { Restricted crop irrigation; } \\
\text { Irrigation for turf } \\
\text { production; Silviculture } \\
\text { and non-food chain } \\
\text { aquaculture }\end{array}$ \\
\hline
\end{tabular}

Note: $\quad N T U=N e p h e l o m e t r i c$ turbidity units; BOD=Biochemical Oxygen Demand; SS=Suspended Solids

Source: South Australian Reclaimed Water Guidelines (Treated Effluent), 1999 
Figure 1: Irrigators' perception of reasons prompting development of the VPS

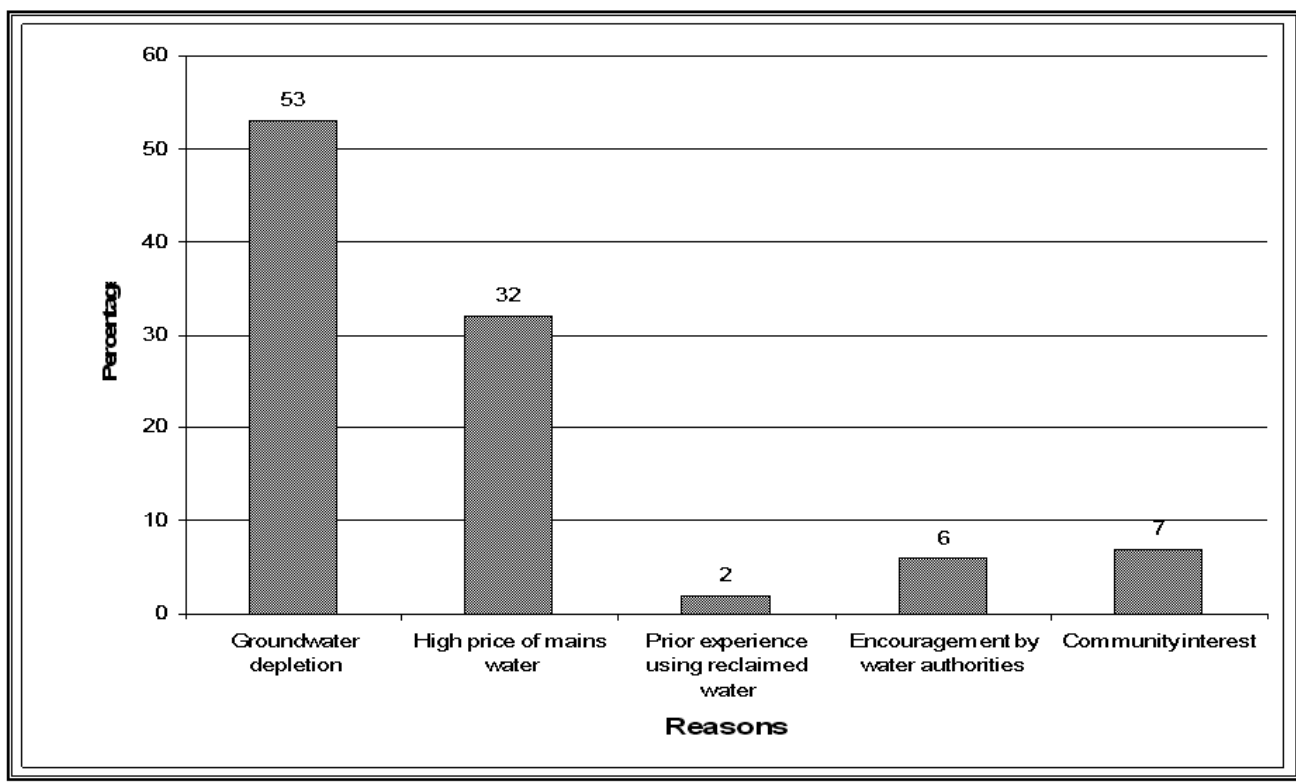

Source: Field Survey

Table 3: Irrigators' perception about collective action and cooperation

\begin{tabular}{|l|c|c|c|}
\hline Statements & Agree & Neutral & Disagree \\
\hline $\begin{array}{l}\text { People in the community will cooperate when there is water supply } \\
\text { problem }\end{array}$ & 58.6 & 14.1 & 27.3 \\
\hline Most people in the community are willing to help when in need & 78.9 & 18.0 & 3.1 \\
\hline This community has prospered in the last five years & 75.8 & 21.9 & 2.3 \\
\hline I feel accepted as a member of this community & 77.3 & 20.3 & 2.3 \\
\hline
\end{tabular}

Source: Field Survey

Figure 2: Irrigator's level of trust in different agencies associated with the scheme 


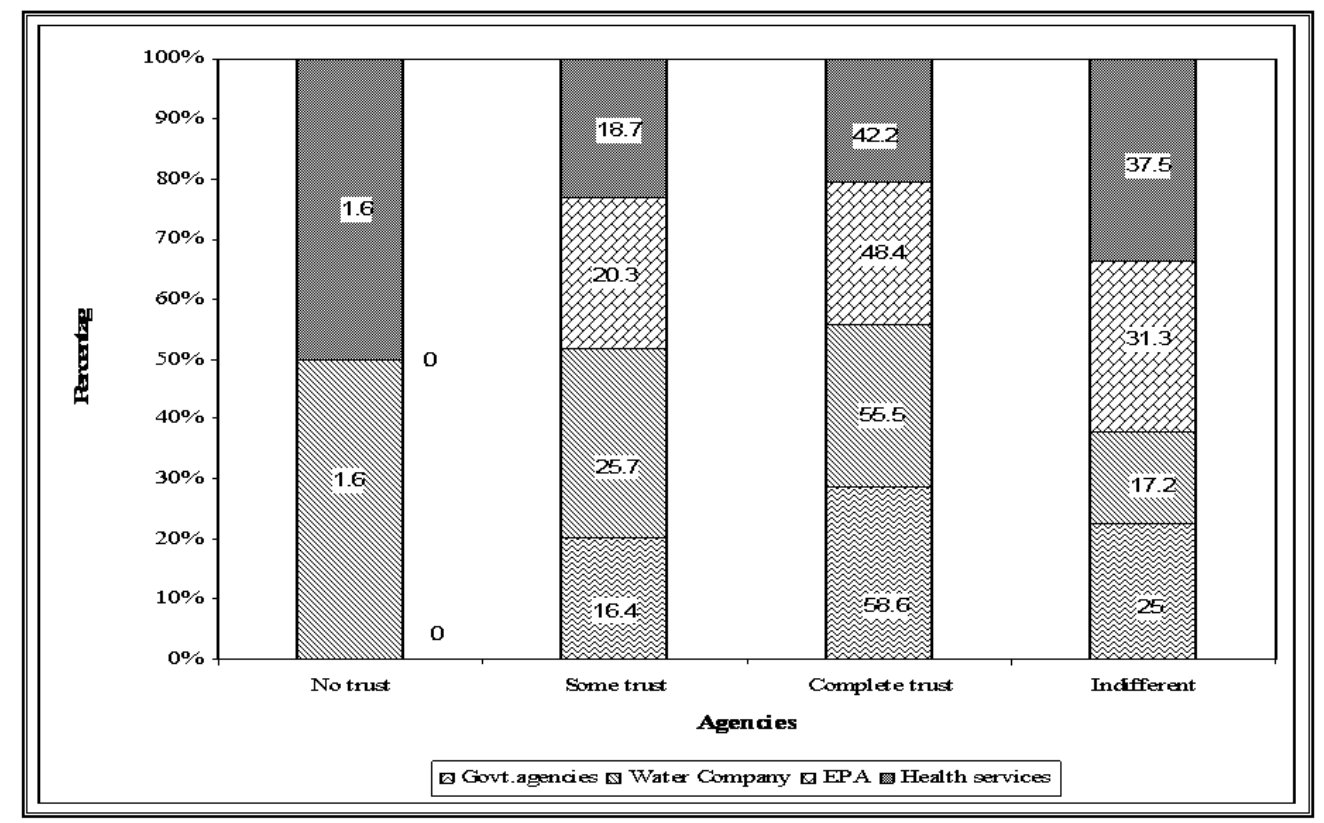

Source: Field Survey 


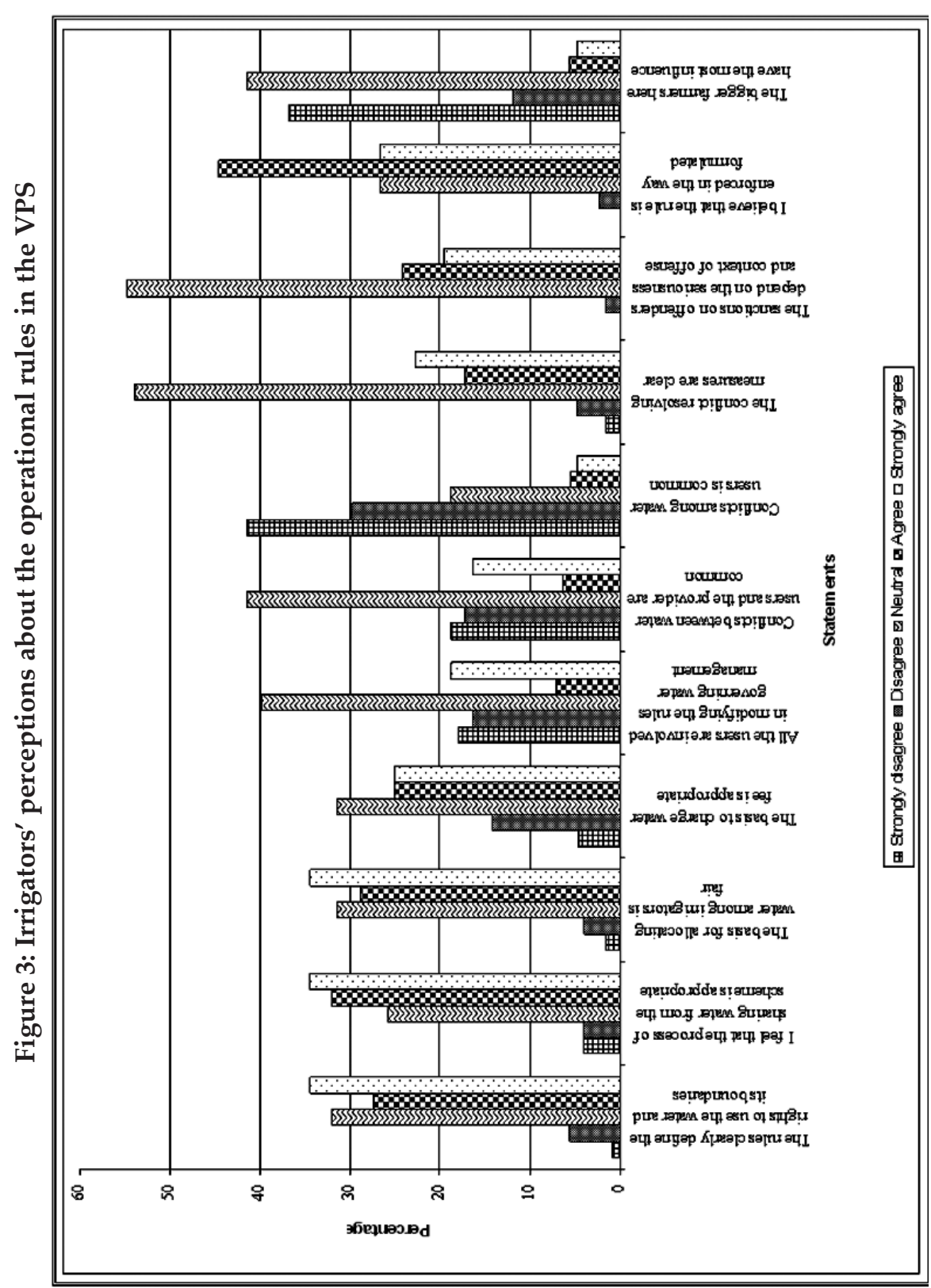

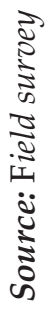

